\title{
A Study of Consumer Attitude Towards Counterfeit Fashion Luxurious Products: The Mediating role of Purchase Intension
}

\author{
Ikramuddin Junejo ${ }^{1}$, Jan Muhammad ${ }^{2}$, Sumaiyah Hassan Ali $^{1}$, Saba \\ Qureshi $^{3}$, Saeed Ahmed Shaikh ${ }^{4}$
}

\begin{abstract}
The aim of this study was to find the factors that influence the students' attitude towards counterfeit fashion luxurious products in Hyderabad, Pakistan. It has been observed that students maintain their social status within the university by purchasing branded but, due to insufficient income leads them to counterfeit products such as Adidas shoes so on. The Primary data has been collected through a survey by distributing questionnaires (face to face) to university students, a total of 330 respondents participated in this research. For the analysis, various statistical tests were performed data such as Factor analysis, Reliability Analysis, and Regression Analysis testing hypothesis in SPSS version 18 and AMOS version 24. Findings revealed that all study variables such as Novelty Seeking, Social Influence, and Social Consumption are mediating by Purchase Intention for consumer's attitudes towards counterfeiting fashion products and partial mediation revealed of these variables. However, university students buy more counterfeits products due to Social Consumption as compare to other factors because the standardized beta value of Social Consumption revealed greater than other variables of this study. Previous scholars measured consumer attitude towards counterfeiting fashion products in terms of female and working men. This study will give insights into university students and Purchase Intention is used as a mediator.
\end{abstract}

Keywords: Purchase Intention, Fashion Luxurious Products, Consumer's Attitude

JEL Code: M31, M37, D11, L67

\section{Introduction}

Counterfeit refers to illegal use of trademarks, patents, and copyright of the certified brand on products that are being manufactured by counterfeiters and are presented at a minor worth and are actually replicas (Veloutsou and Bian, 2008). There are 2 types of counterfeiting done on genuine goods. First is deceptive counterfeiting and the second is non-deceptive copying. The misleading fake things are sold in the marketplace deliberately to mislead the consumers (Penz and Stottinger, 2008). The willingness to repurchase and buy counterfeit as a substitute for any product defines customer purchasing conduct (Phau et al., 2009).

\footnotetext{
${ }^{1}$ Department of Management Sciences, SZABIST Hyderabad Campus

${ }^{2}$ Jiangsu University, Zhenjiang, China

${ }^{3}$ University of Sindh Jamshoro, Pakistan

${ }^{4}$ Wuhan university of technology, China

Corresponding Author: $5103190207 @$ stmail.ujs.edu.cn
} 
When the consumers are not capable of purchasing original goods due to the high prices they demand and prefer buying counterfeit of it because of the reasonable prices of them. Counterfeiting is being very common and is promptly growing globally in both under developing as well as developing countries. It refers to an uncertified representation of certified products with a purpose to cheat the buyer through creating them accept as true that consumer is purchasing the genuine products (WTO,2017). Counterfeiting famous fashion luxury brands has now become a crucial problem globally (Triandewi and Tjiptono, 2013). Recent research by Mark Monitor (2018), found that around 47\% of brands are failing to cash due to counterfeiting, with one in three saying the decline in sales corresponds to more than $10 \%$ and with four in ten businesses have experienced an increase in the counterfeiting who are involved in selling unauthorized brands by breaching laws of authorized brands.

According to OECD and EUIPO (2016), the intensification of counterfeit products has been notified by the countries worldwide, it is estimated that the world's five percent products are counterfeit. Also due to counterfeiting about two hundred billion US dollars, a year contributes and as a result, various negative impacts revealed such as unemployment, reduction in sales of original products, and government revenue badly affected (Furnham and Valgeirsson, 2007).

The past two decades have witnessed a rapid growth in counterfeiting which has now become an important political, social, and economic issue worldwide (Cant, et al., 2014). Counterfeiting has become a crime of 21 st century not only due to reason of violating laws and affecting profits of businesses of all sectors but it is also causing serious health and safety risks for consumers using counterfeit products which is ultimately causing heavy bleeding in the global economy (Schneider and Bikoff, 2015). According to (ICC) International Chamber of Commerce (2017) globally faking and piracy is continuously rising at an astonishing level and it is forecasted that by 2022 counterfeiting possibly will increase up to the US \$2.3 trillion. According to Organization for Economic Cooperation and Development (OECD) and European Union Intellectual Property Office (EUIPO), the international trade of counterfeited and bootlegged goods is worth \$461 Billion, which was $2.5 \%$ of international trade in 2013 and could reach to $\$ 991$ Billion by 2022. The key motive for the continuous progress and presence of copying products within the country is due to the rapid growth of consumer demand which is the driving force of the market and results in the growth of counterfeiting globally (Ang et al., 2001).

The press release of Tribune International by (Ghauri, 2014), Pakistan has been ranked thirtieth nation in the world where replica and counterfeit products including medicines, foodstuffs of all kinds, soaps, cosmetics, perfumes, and consumer goods especially luxurious fashion products are produced and are floating freely in the market in huge amount. About $65 \%$ of consumer goods are counterfeits that have put the well-being and care of the persons in great danger, as their contents are never tested. Manufacturers of original and genuine products, government revenue, and 
buyers of counterfeits are all facing harmful effects because of the free-floating of counterfeit brands in the country.

Marketers must understand the "Black Box" and develop strategies for responding to stimuli. The black box model indicates "how a consumer is responding to stimuli in terms of the decision process, consumer characteristics and consumer responses interact (Sandhusen, 2000). Blackwell et al., (2001), developed model so call tripartite model that explains the attitude. In this model, they suggested that attitude is consists of three important components such as cognitive component (known as beliefs), affective component (Known as feelings or emotions), and last a conative component (known as a behavioral intention).

Due to the rise in counterfeits in Pakistan today, it is essential to figure out which elements force consumers to buy counterfeit goods. This paper will help the company's manufacturing genuine goods, to design an appealing marketing strategy by knowing the attitude of people towards the intention to purchase and reasons for shifting their demand towards counterfeited goods. Earlier investigates devices by now been directed in different countries such as Malaysia, Indonesia, Vietnam, etc. to know the attitude and intention to purchase counterfeits. Therefore, the reason for researching in Hyderabad, Pakistan is to fill the research gap by knowing the consumer buying pattern of university students of Hyderabad which might vary in comparison to other countries due to the influence of country-specific factors for which a study should be conducted to explore these factors.

\section{Empirical Literature Review and Development of Hypothesis}

\subsection{Theoretical Framework}

\subsubsection{Consumer Decision Model}

In the field of marketing, many well-studied models are suggested by various scholars such as Howard and Sheth (1969), Engel et al., (1968). These models find out the psychological state of a consumer in which consumers try to satisfy themselves by purchasing goods and services after depth evaluation of alternatives. Another study developed by Festinger (1957), in the theory of cognitive dissonance of the end consumer, in which he suggested the future purchase has a great influence on the decision process. Engel and Blackwell (1982), recommended that the environmental influence which may also affect the final decision of consumer with respect to intention and motivation to buy goods and services. However, they suggested that there are certain uncontrolled factors that may influence this process such as insufficient funds and unavailability of the desired brand into the market. This model assumed the intrapersonal psychological events and states from intention to attitude.

\subsubsection{Stimulus-Response Model}

In the field of marketing, buyers enter the "Black Box" and develop a few choices for purchasing goods and services. Marketers must understand the "Black Box" and develop strategies for responding to stimuli. The black box model indicates "how a 
consumer is responding to stimuli in terms of the decision process, consumer characteristics and consumer responses interact (Sandhusen, 2000). The black box model is associated with the theory of behaviorism, in this theory consumer not related insight process of consumer and relationship with stimuli as well. Environmental stimuli are mainly based on social factors and economic and cultural in a specific society.

\subsubsection{Tripartite Model}

Blackwell et al., (2001), developed model so call tripartite model that explains the attitude. In this model, they suggested that attitude is consists of three important components such as cognitive component (known as beliefs), affective component (Known as feelings or emotions), and last a conative component (known as a behavioral intention). The relationship between attitude and behavior seems to be stronger in the case of the shorter time interval and in other situations the attitudes may expression of behavior itself. In these situations, consumers adopt a certain attitude based on behavior.

\subsection{Mediator Purchase Intention}

Attitude refers to the inclination of an individual to behave in a likely or unlikely manner regarding their buying behavior. Attitude is a persistent behavior that how a person responds in a particular situation in a favorable or unfavorable way. (Huang et al., 2004). Attitude is a psychological position that people used to perceive the environment. According to $\mathrm{Wu}$ et al. (2011), Purchase intention refers to the consumer's likelihood to purchase certain products or services in the future.

Therefore, the attitude of people towards counterfeiting products is significant. Nordin (2009) considered variables such as price consciousness, normative susceptibility, perceived risk, and novelty seeking as determinants of consumer behavior to buy counterfeits. Based on results Nordin concluded that consumers most favorable have the intention to buy counterfeited goods. Attitude has a direct relation to the consumer's behavior. Therefore, there is a high chance that people will purchase counterfeit goods, if, they have a favorable attitude towards counterfeiting products. Although people think that counterfeits do not have similar benefits as compared to genuine, but consumers find it advantageous when buying counterfeit fashion products (Krishnan et al., 2017).

Pakistani consumers purchase counterfeit products and do not put much attention to the quality aspects of counterfeit (Hussain et al., 2017). Past buying experience strongly affects the consumer's purchase intention of counterfeited luxury goods. Whereas it further states that people who buy counterfeits of luxury goods have an intention to buy original goods and people who buy original products of luxurious companies does not have an intention to buy counterfeits of it. This indicates that consumers purchasing counterfeit will most probably switch to buying originals over time and would not return to counterfeits again (Yoo and Lee, 2009). Either people choose to buy original fashion luxury products or counterfeits depends upon multiple factors like income, shopping convenience, hedonic purposes, etc. While 
buying there are numerous factors that affect consumer attitude towards counterfeits but purchase intention is an important and vital factor to know consumer-buying behavior (Phau and Teah, 2009).

\subsection{Novelty Seeking and Consumer's Attitude}

The word novelty seeking is defined as the consumer's behavior to search for a unique and new variety of products. Therefore, the people who like to keep themselves stick with the latest trends will be seen inclined to try new and latest products and designs. Consumers will preferably buy counterfeit goods by putting low cost and continuously changing their styles and remains up to date (Krishnan et al., 2017).

According to Wang et al., (2005), people always search for unique and different products. The results of this study suggested that after price, novelty is the strongest influencing element of intention to purchase counterfeits of luxury brands. Many factors affect consumer buying behavior in fashion products. However, people forget an ordinary product and rush for novelty if the product is unique (Yoo and Lee, 2009). Consumers always demand new and latest fashion products and if they are expensive, they go for their counterfeits available at a low price (Nordin, 2009). Consumers support counterfeit products more because they most likely want to follow the latest trend at low prices knowing that it is less chosen but then also they buy just to enjoy the novelty and present themselves differentiated from others (Harun et al., 2012). So the following hypothesis is presented:

- H1a: Novelty Seeking relates positively to Consumer Attitude.

- H1b: Purchase Intention mediating relationship between Novelty Seeking, Consumer Attitude.

\subsection{Social Influence and Consumer's Attitude}

The word Social Influence means the effect that people around or social circles like family members, colleges, and friends make on a person by influencing its buying behavior. The suggestions from the reference group influence the decision of people to either buy counterfeits or original fashion luxury brands (Wang et al., 2005, Phau and Teah 2009). According to Krishnan et al., (2017), consumers not usually take advice from their peer groups for their counterfeit purchases and they also do not recommend their friends and relatives because of financial conditions.

Hidayat and Diwasasri (2013), in their study, defines factors like "communalism, peer pressure, susceptibility towards social influence and family", which impact the consumer decision to buy counterfeit products or not. Eisend and Guler, (2006), they stated that reference groups have the power to influence purchaser mindset related to brand image and brand. Reference groups and consultants influence consumer behavior. Consumers do understand, if their friends or relationships around them support the specific brand, they are interested in buying (Phau et al., 2009). So the following hypothesis is presented.

- H2a: Social Influence relates positively to Consumer Attitude.

- H2b: Purchase Intention mediating the relationship between Social Influence, Consumer attitude.

Sukkur IBA Journal of Management and Business - SIJMB | Vol 7 No. 1 January - June 2020 @ Sukkur IBA University 


\subsection{Social Status and Consumer's Attitude}

The word status means the position and lifestyle that a person holds based on honor, respect, and prestige in the society (Ergin, 2010). Social status defines the position of a person in society. Social norms are single of the reason that upset the shoppers' willingness to purchase branded products (Tang et al., 2014). People prefer to buy those products which display their high status through which global companies increase their revenues by serving those products to consumers (Krishnan et al., 2017).

According to Kwak and Sojka (2010), people living abroad and outside their home countries have a strong association with their ethnic culture and they pay for branded products portraying their national culture to show their social status. Snob appeal attracts people to purchase elite products to distinguish themselves from other people (Husic and Cicic, 2009). The increase in demand for luxury goods shows that status can cause damage to the financial progress of the nation in the long run as consumers are more concerned about their social standings and esteem (Phau et al., 2009).

According to Mukhtar (2016), people purchase patented goods in a mandate to prompt their respect and position in front of people in their around and create a positive approach in the direction of fake goods leading towards buying purpose. Consumers having lower status generally buy counterfeit goods for showing their higher position (Budiman, 2012). The reason for buying a counterfeit product is to express the class, image that it makes towards the society, and to see how people view those (Yoo and Lee, 2009). Status consumers are more conscious about how they present and display themselves in front of others because to them it expresses prestige and status (Phau and Teach, 2009).

When a product represents high status the people possessing characteristics of status consciousness most preferably buy and are even ready to pay more for consuming that product. The status-conscious consumers do not share about their purchase of counterfeit products in the forward-facing of noble individuals and domestic associates because they feel that their image will get hurt. Therefore, the following hypothesis is proposed:

- H3a: Social Status relates positively to Consumer Attitude.

- H3b: Purchase Intention mediating the relationship between Social Status, Consumer Attitude.

Based on the above theoretical framework and literature review following the conceptual frame of this study has been developed. 


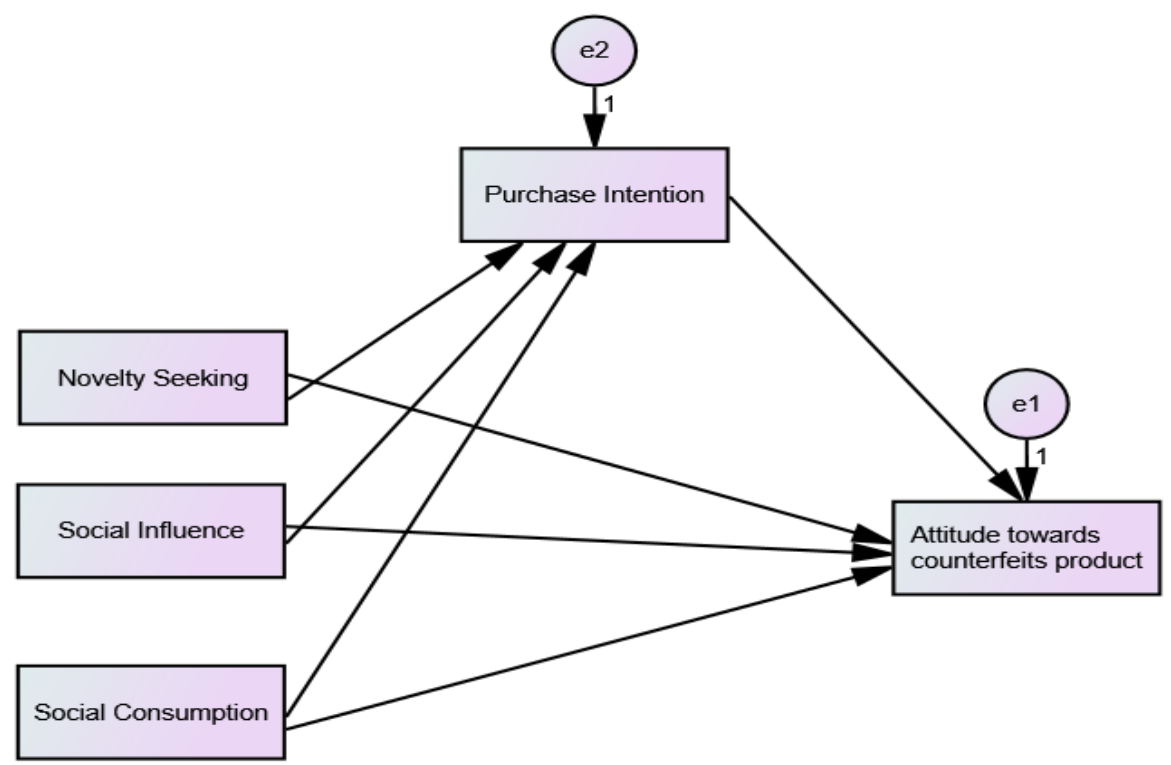

Figure 1: Conceptual Framework (Source: This Study)

\section{Methodology}

In this study, respondents were nominated via convenience sampling techniques. The convenience sampling technique is a non-probability sampling, it is used when the researcher was unable to select respondents in the study (Malhotra, 2010). The convenience techniques were adopted for data collection due to counterfeit is a very sensitive topic and most respondents reluctant to respond to asked questions. In order to reduce this effect, the respondents were informed that the data has been collected for academic research purpose only and they will ensure that their responses will remain confidential and no privacy will be effective through this study.

Primary data has been collected with the help of adopted questionnaire from previous studies. Most of the time adopted questionnaires reveal reliability and validity for data collection. Data were collected to test the above-proposed hypothesis. The questionnaire was consisting of structural close-ended questions with two parts. In the first part of the questionnaire, the respondents filed the personal profile and the second part of the questionnaire was included both dependent and independent variables were measured. The questionnaire's second part was adopted from previous studies and all the independent and dependent variables were measured from studies of Nguyen and Tam (2015), Nguyen and Tran (2013), and Nordan (2009). The questionnaire was consisting of five Likert scale from negative to positive approach ranges from Strongly Disagree (1) to Strongly Agree (5), University students were asked to fill the questionnaire (face to face). Furthermore, the questionnaire did not comprise any specific counterfeit brands, as Sukkur IBA Journal of Management and Business - SIJMB | Vol 7 No. 1 January - June 2020 ๑ Sukkur IBA University 
Ikramuddin Junejo et al A Study of Consumer Attitude Towards Counterfeit Fashion Luxurious Products: The Mediating role of Purchase Intension (pp 1-18)

in this study, it measured the consumer attitude and purchase intention counterfeit products as an entire. The university students from Hyderabad, Pakistan were asked to respond to questions for concluding this study.

For the sample size rule of thumb for survey method formula was:

$\mathrm{N}=$ No of items in questionnaire X 10

In this study a total number of items were 18 , hence sample size was calculated as:

$$
\mathrm{N}=18 \mathrm{X} 10=180
$$

The required sample size from university students was 180 but to get reliable results, 330 university students were asked to fill the questionnaire (face to face). They were told to fill a questionnaire and return it within a little time. The data has been collected in 1 week from a total of 330 university students, however, during data cleaning and screening only 250 printed questionnaires were considered for the analysis purpose. Based on this number response rate was 75.7 percent.

\section{Result and Discussion}

\subsection{Descriptive Analysis:}

The total questioners filled in this research were 250 out of 330 distributed to students in University students of Hyderabad. The last question of the profile was asked to easily identify the students who had not purchased counterfeits so that their responses would not be included. As the data analysis would only be done of those respondents who had purchased counterfeits of fashion luxury products. The 75.7\% response rate includes both male and female students in which $43.2 \%$ were males and $56.8 \%$ were females as summarized in table 1.

Table 1: Respondent Profile (source: This study)

\begin{tabular}{|c|c|c|c|}
\hline Construct & Category & Frequency & Percentage \\
\hline \multirow{2}{*}{ Gender } & Male & 108 & $43.2 \%$ \\
\hline & Female & 142 & $56.8 \%$ \\
\hline \multirow{2}{*}{ Marital status } & Single & 203 & $81.2 \%$ \\
\hline & Married & 47 & $18.8 \%$ \\
\hline \multirow{5}{*}{ Monthly Income } & Less than 10,000 & 60 & $24 \%$ \\
\hline & 10-20 thousand & 27 & $10.8 \%$ \\
\hline & $20-30$ thousand & 36 & $14.4 \%$ \\
\hline & More than 30,000 & 42 & $16.8 \%$ \\
\hline & None & 85 & $34 \%$ \\
\hline \multirow{3}{*}{ Program } & BBA & 120 & $48 \%$ \\
\hline & MBA & 67 & $26.8 \%$ \\
\hline & BSCS & 63 & $25.2 \%$ \\
\hline \multirow{2}{*}{$\begin{array}{l}\text { Have you } \\
\text { purchased } \\
\text { counterfeit } \\
\text { products? }\end{array}$} & Yes & 250 & $75.7 \%$ \\
\hline & No & 80 & $24.2 \%$ \\
\hline
\end{tabular}

Sukkur IBA Journal of Management and Business - SIJMB | Vol 7 No. 1 January - June 2020 @ Sukkur IBA University 


\subsection{Factor Analysis (Exploratory)}

The Factor Analysis (Exploratory) applied individually for each study. Hair et al., (2010), EFA is used to apply for ensuring the reduction in items for each construct should be decreased at a great level. The cut-off value for KMO should be 0.50 and Bartlett's test of septicity should be less than 0.05 . Furthermore, according to Kaiser's (1958), the eigenvalue should be 1 or greater than 1 . The factor loading value would be at minimum 0.35 or larger to achieve the level of significance and further statistical test analysis.

Table 2: Unidimensionality and Convergent Validity

\begin{tabular}{|c|c|c|}
\hline Constructs & Indicator (parameter) & Factor loadings \\
\hline Novelty Seeking & $\begin{array}{l}\alpha=.723, \text { AVE }=0.637 \\
\text { I always want to be the first one } \\
\text { to try new fashion products. } \\
\text { I own a lot of popular fashion } \\
\text { products. } \\
\text { I keep up with fashion. }\end{array}$ & $\begin{array}{l}0.783 \\
0.843 \\
0.766\end{array}$ \\
\hline Social Influence & $\begin{array}{l}\alpha=.701, \mathrm{AVE}=0.55 \\
\text { People around me buy } \\
\text { counterfeit luxurious fashion } \\
\text { products. } \\
\text { It is acceptable in my society to } \\
\text { buy counterfeit of luxurious } \\
\text { brand products. } \\
\text { People around me encourage } \\
\text { me to buy counterfeit luxurious } \\
\text { fashion products. }\end{array}$ & $\begin{array}{l}0.768 \\
0.845\end{array}$ \\
\hline Social Consumption & $\begin{array}{l}\alpha=.794, \text { AVE }=0.625 \\
\text { I would pay more for a fashion } \\
\text { product if it has status. } \\
\text { A product is more valuable to } \\
\text { me if it has a high status. } \\
\text { I would buy a fashion product } \\
\text { just because it has a status. }\end{array}$ & $\begin{array}{l}0.757 \\
0.866 \\
0.744\end{array}$ \\
\hline $\begin{array}{l}\text { Attitude towards } \\
\text { counterfeits product }\end{array}$ & $\begin{array}{l}\alpha=.737, \mathrm{AVE}=0.648 \\
\text { Buying counterfeit of luxurious } \\
\text { brand fashion products } \\
\text { generally benefits the } \\
\text { consumer. } \\
\text { Buying counterfeit of luxurious } \\
\text { brand fashion products is a } \\
\text { better choice. } \\
\text { Counterfeit of luxurious } \\
\text { fashion products provide } \\
\text { functions similar to genuine }\end{array}$ & $\begin{array}{l}0.366 \\
0.682\end{array}$ \\
\hline
\end{tabular}

Sukkur IBA Journal of Management and Business - SIJMB | Vol 7 No. 1 January - June 2020 @ Sukkur IBA University 


\begin{tabular}{|l|l|l|}
\hline & $\begin{array}{l}\text { products. } \\
\text { Counterfeit luxurious fashion } \\
\text { products are as reliable as } \\
\text { genuine products. }\end{array}$ & 0.575 \\
\hline $\begin{array}{l}\text { Purchase Intention } \\
\text { product }\end{array}$ & $\begin{array}{l}\alpha=.756, \text { AVE }=0.465 \\
\text { I think about a counterfeited of } \\
\text { luxurious brand fashion product } \\
\text { as a choice when buying } \\
\text { something. } \\
\text { I buy counterfeit luxurious } \\
\text { fashion products if I think } \\
\text { genuine designer products are } \\
\text { too expensive. } \\
\text { I recommend friends and } \\
\text { relatives to buy a counterfeited } \\
\text { luxurious fashion product. } \\
\text { I intend to buy counterfeit } \\
\text { luxurious products in the future } \\
\text { due to my financials. } \\
\text { My willingness to buy } \\
\text { counterfeit products is high. }\end{array}$ \\
\hline
\end{tabular}

Note: **significance level at 0.05

Source: Author's Estimation

Method: Component factor analysis (Varimax)

Table 2, revealed that all variables (Novelty seeking, Social influence, Social consumption, Attitude towards counterfeits products, and Purchase Intention towards counterfeits products). All the 18 items of these constructs have factor loading greater than 0.35 . The value of Eigenvalue is greater than 1 and the total variance explained is $65.8 \%, 60 \%, 61.1 \%, 73.7 \%$, and $75.6 \%$ respectively. The value of KMO is also greater than 0.50 and level of significance (p-value) all abovestated variable has less than 0.05. Based on this result of Exploratory Factor Analysis confirmed that we can now apply further statistical tests for the analysis.

\subsection{Reliability Analysis}

Table 3: Summarizes the Results of Reliability Analysis

\begin{tabular}{|l|l|l|}
\hline Name of variable & Cronbach's Alpha & No of Items \\
\hline Novelty Seeking & 0.713 & 3 \\
\hline Social Influence & & \\
\hline & 0.642 & 3 \\
\hline
\end{tabular}


Ikramuddin Junejo et al A Study of Consumer Attitude Towards Counterfeit Fashion Luxurious Products: The Mediating role of Purchase Intension

\begin{tabular}{|l|l|l|}
\hline Social Consumption & 0.691 & 3 \\
\hline Attitude towards counterfeits product & 0.724 & 4 \\
\hline Purchase Intention & 0.708 & 5 \\
\hline
\end{tabular}

Source: Author's Estimation

You are able to get in above table 3, in our case Cronbach's Alpha value of Novelty Seeking (71.3\%), Social Influence (64.2\%), Social Consumption (69.1\%), Attitude towards counterfeits product $(72.4 \%)$ and Purchase Intention towards counterfeits product $(70.8 \%)$. All the studied variables are found reliable and the decision for reliability can be suggested that the data is consistent.

\subsection{Hypothesis Testing}

Table 4: Regression Weights

\begin{tabular}{|c|c|c|}
\hline \multirow{2}{*}{$\begin{array}{c}\text { Variable } \\
\text { (Independent variables) }\end{array}$} & $\beta$ (Standard coefficient) & Significance value \\
\cline { 2 - 3 } & 0.163 & $.024^{* *}$ \\
\hline Novelty Seeking & 0.162 & $.009^{* *}$ \\
\hline Social Influence & 0.205 & $.004^{* *}$ \\
\hline Social Consumption & 0.163 \\
\hline R-Square
\end{tabular}

Note: **significance level at 0.05

Source: Author's Estimations

A coefficient table 4, shows two important values, the value of beta and p-value. The value of beta usually determines the relationship among variables, whereas probability value shows the level of significance. In this study, all studied variables such as Novelty Seeking (NS), Social Influence (SI), and Social Consumption are revealed positive and significant relationship attitudes towards counterfeits product (ATCP) in the context of Hyderabad, Pakistan. Hence hypotheses such as H1a, H2a, H3a have been supported. 


\subsection{Mediation Results}

\subsubsection{Novelty Seeking}

Table 5: Summarize the Mediation Results (Novelty Seeking)

\begin{tabular}{|l|c|c|c|}
\hline \multicolumn{1}{|c|}{ Construct } & $\mathrm{B}$ & $\mathrm{R}^{2}$ & Significant value \\
\hline$* \mathrm{NS}->\mathrm{CA}$ & 0.552 & 0.354 & .004 \\
\hline$* * \mathrm{NS}->\mathrm{CA}$ & 0.402 & 0.089 & .012 \\
\hline$* * * \mathrm{NS}->\mathrm{PI}->\mathrm{CA}$ & 0.150 & 0.070 & .005 \\
\hline
\end{tabular}

Note: NS=Novelty Seeking, CA=Consumer Attitude, PI=Purchase Intention

*Total Effect

*Direct Effect

*Indirect Effect

You can see in the table- 5, indicates that three effects such as total effect, direct effect, an indirect effect on Consumer attitude with the mediating role of purchase intention. The total effect between Novelty seeking and Consumer attitude positive (Beta=0.552) with a value of R2 0.354 and statistically found significant (pvalue $=.004)$. The direct effect between Novelty seeking and Consumer attitude positive (Beta=0.402) with a value of R2 0.089 and statistically found significant ( $\mathrm{p}$-value=.012). The indirect effect between Novelty seeking, Purchase intention, and Consumer attitude positive (Beta=0.15) with the value of R2 .07 and statistically found significant ( $\mathrm{p}$-value $=.005$ ) respectively. Based on these findings proposed hypothesis $\mathrm{H} 1 \mathrm{~b}$ has been supported and mediation analysis revealed partial mediation. Furthermore, the direct effect $(b e t a=0.402)$ is stronger than the indirect effect $(0.15)$ due to beta standardized value of the direct effect is greater than the indirect effect.

\subsubsection{Social Influence}

Table 6: Summarize the Mediation Results (Social Influence)

\begin{tabular}{|l|c|c|c|}
\hline \multicolumn{1}{|c|}{ Construct } & $\beta$ & $\mathrm{R}^{2}$ & Significant value \\
\hline *SI->CA & 0.435 & 0.281 & .000 \\
\hline **SI->CA & 0.322 & 0.015 & .004 \\
\hline ***SI->PI->CA & 0.103 & 0.120 & .020 \\
\hline
\end{tabular}

Note: SI=Social Influence, CA=Consumer Attitude, PI=Purchase Intention

*Total Effect

*Direct Effect

*Indirect Effect

Sukkur IBA Journal of Management and Business - SIJMB | Vol 7 No. 1 January - June 2020 ○ Sukkur IBA University 
You can see in table-6, illustrates that three effects such as total effect, direct effect, an indirect effect on Consumer attitude with the mediating role of purchase intention. The total effect between Social influence and Consumer attitude positive (Beta=0.435) with a value of R2 0.281 and statistically found significant (pvalue=.000). The direct effect between Social influence and Consumer attitude positive (Beta=0.322) with the value of R2 .0153 and statistically found significant (p-value=.004). The indirect effect between Social influence, Purchase intention, and Consumer attitude positive $(B e t a=0.103)$ with a value of R2 .012 and statistically found significant ( $\mathrm{p}$-value $=.020)$ respectively. Based on these findings proposed hypothesis $\mathrm{H} 2 \mathrm{~b}$ has been supported and mediation analysis revealed partial mediation. Furthermore, the direct effect (beta $=0.322)$ is stronger than the indirect effect $(0.103)$ due to the beta standardized value of the direct effect is greater than the indirect effect.

\subsubsection{Social Consumption}

Table 7: Summarize the Mediation Results (Social Consumption)

\begin{tabular}{|l|c|c|c|}
\hline \multicolumn{1}{|c|}{ Construct } & $\mathrm{B}$ & $\mathrm{R}^{2}$ & Significant value \\
\hline$*$ SC->CA & 0.485 & 0.394 & .000 \\
\hline **SC->CA & 0.331 & 0.018 & .002 \\
\hline ***SC->PI->CA & 0.154 & 0.140 & .021 \\
\hline
\end{tabular}

Note: $\mathrm{SC}=$ Social Consumption, $\mathrm{CA}=$ Consumer Attitude, $\mathrm{PI}=\mathrm{Purchase}$ Intention

*Total Effect

*Direct Effect

*Indirect Effect

You can see in table 7, indicates that three effects such as total effect, direct effect, an indirect effect on Consumer attitude with the mediating role of purchase intention. The total effect between Social consumption and Consumer attitude positive (Beta=0.485) with a value of R2 0.394 and statistically found significant ( $\mathrm{p}$-value=.000). The direct effect between Social consumption and Consumer attitude positive $(B e t a=0.331)$ with the value of $\mathrm{R} 2.018$ and statistically found significant ( $\mathrm{p}$-value $=.002$ ). The indirect effect between Social consumption, Purchase intention, and Consumer attitude positive $(B e t a=0.154)$ with a value of R2 .14 and statistically found significant ( $\mathrm{p}$-value=.021) respectively. Based on these findings proposed hypothesis $\mathrm{H} 3 \mathrm{~b}$ has been supported and mediation analysis revealed partial mediation. Furthermore, the direct effect (beta $=0.331$ ) is stronger than the indirect effect (0.154) due to the beta standardized value of the direct effect is greater than the indirect effect.

Sukkur IBA Journal of Management and Business - SIJMB | Vol 7 No. 1 January - June 2020 @ Sukkur IBA University 


\subsection{Discussion on Results}

First, the result concluded is strong and it gives a clear picture that students of Hyderabad's students purchase counterfeit products because of factors like Novelty Seeking Social Influence, and Social Consumption. Consumers with low-income support counterfeiting. Second, previous scholars also concluded the same results in their studies related to this study such as Santi (2012), her study revealed that attitude has a significant impact on counterfeiting on bag products in Indonesia and higher status among women was a unique finding of this study. Yoo and Lee (2009), luxuries counterfeits product purchase intention in Korea. Their findings showed that many consumers buy luxuries counterfeits due to economic benefits, cheaper rates attract them for buying such products for future use. Finally, factors influencing buy luxuries counterfeits products. In this study, their results revealed that celebrity endorsement along with the marketing mix in luxury products leads to purchase intentions among consumers (Stravinskiene et al., 2013).

\section{Theoretical Contribution}

This study based on university students has both theoretical and piratical contributions. First, In the context of theoretically, this study has suggested new linkages among Novelty seeking, Social Influence, and Social Consumption to an attitude in the presence of Purchase Intention. In this study, the authors used the tripartite model that explains the attitude.

Second, The Consumer decision model is used in this study as a theoretical framework, that suggested the environmental factors such as Social Influence and Social Consumption. These factors will have a significant influence on the final consumer purchase intention and motivation to buy products. In this model, the authors mentioned there are uncontrolled factors such as insufficient funds and the unavailability of desired brands in the market. This study supports this augment of a consumer decision model that Hyderabad university students may attract towards counterfeits products due to lack of income and inaccessibility of demanded brands into the Hyderabad market.

Third, the Stimulus-response model is also applied in this study as a theoretical framework, which is also known as the "Black box model" that explained environmental stimuli that are based on social factors in the society. This study supported this model in terms of theory as well because social factors are considered in this paper such as Social Influence and Social Consumption are used and the results of this paper revealed that university students' of Hyderabad, Pakistan as their consumer behavior is supported for purchasing the counterfeits products.

Fourth, this is a new study that verified the mediating role of purchase intention between Novelty seeking, Social Influence, and Social Consumption in regard to counterfeit fashion products. This would be a significant contribution to the theory of consumer behavior in regard to university students with low-income factors.

Sukkur IBA Journal of Management and Business - SIJMB | Vol 7 No. 1 January - June 2020 @ Sukkur IBA University 


\section{Managerial Implication}

First, this study would be a new insight for managers in the context Hyderabad, Pakistan with respect to fashion product counterfeit. The outcome of this study focused on social factors in terms of Social Influence and Social Consumption that the ethical perspective not to buy fake products that have a negative impact on both firms and society as well in the long run.

Second, the government bodies and key decision-makers in Hyderabad, Pakistan should observe this behavior in the education system like universities, in order to protect or discourage the current behavior and for improving the quality of life among university students. Lastly, the seminars and conferences should be organized in both private and public universities in order to address the issue of fake products and recommending possible strategies related to fashion products for minimizing this effect in the future.

\section{Limitations and Research Direction for Future}

This study provides insights for counterfeits products from Hyderabad, Pakistan but there are certain limitations. First, the inadequacy of this research is that due to convenience sampling and limited time the data was collected only from students of University students Hyderabad.

Second, this research only focused on counterfeit fashion luxury products whereas counterfeit is done of other product categories also as well. So, to completely comprehend the consumer's perception and purchase intention towards counterfeit future research could be conducted including other counterfeit range of products for better understanding the consumers' perception. Factors such as Price consciousness, Personal gratification, perceived risk, Integrity, product Involvement, materialism, past experience, and more were not included in this research.

Third, the recent study conducted by Gilal et al., (2018), the relationship between product design and consumer behavior in terms of negative word-of-mouth and willingness to pay. They have compared both male and female, in the context of Pakistan results revealed that men are more aesthetic and hedonic as compare to women. These findings were oppositive in regards to China. So, based on these findings it can be concluded that gender behavior may respond differently with respect to the country or culture.

Fourth, another recent study by Gilal et al., (2018), nexus between parent's brand passion and child's brand passion by using socialization theory and emotional contagion theory. The findings of this suggested that parents' airline passion translated into the child's airline passion in relationships with daughter and son without any geographical distance.

Finally, moderate mediation of age and gender explored in the latest study by Gilal et al., (2018). In this study, the authors used an organismic integration theory and linking motivational regulation to brand passion. The moderation results revealed that women have more brand passion in the perspective of intrinsic motivation than Sukkur IBA Journal of Management and Business - SIJMB | Vol 7 No. 1 January - June 2020 @ Sukkur IBA University 
men, however, the external motivation seems to salient for the case of men as compared to women. Furthermore, with respect to age older customers have more brand passion due to external motivation and parental motivation is found more among young customers as compare to aged customers. Based on these studies, it is highly recommended that in future the moderated mediation analysis also can be performed in terms of Age and gender in the future in regard to counterfeit products for fashion products.

\section{Conclusion}

Factors including Novelty Seeking, Social Influence, and Social Consumption were taken to know the influence on the attitude of students towards counterfeit fashion luxury goods. Whereas this research it was also proposed that the attitude of students affects the intention to purchase fake fashion extravagance products. The findings of this research showed that all university students such as Business and non-business students are buying luxuries counterfeits producers due to similar above-stated factors in this study. Students for social concern prefer to buy counterfeits products for sake acceptance in their social circle. This attitude towards counterfeits luxury products leads them to purchase intention towards counterfeits products.

\section{References}

Ang, S.H., Lim, E.A.C., Cheng, P.S., and Tambya, S.K. (2001), "Spot the Difference: Consumer Responses Towards Counterfeits", Journal of Consumer Marketing, Vol. 18(3), 219-235.

Budiman, S. (2012), "Analysis of Consumer Attitudes to Purchase Intention of Counterfeiting Bag Products in Indonesia", International Journal of Management, Economics and Social Sciences, Vol. 1(1), 01-12.

Blackwell, R., Miniard, P. and, Engel, J. (2001), "Consumer Behavior”. 9th ed., Fort Worth, TX. Harcourt College Publishers.

Cant, M.C., Wiid, J., A. and Manley, L., L. (2014), "Counterfeit Luxury Fashion Brands: Consumer Purchase Behaviour, "Corporate Ownership and Control, Vol. 11(3), 21 33.

Eisend, M., and Guler, P. (2006)," Explaining Counterfeit Purchases: A Review and Preview", Academy of Marketing Science Review, Vol. 12(1), 01-21.

Ergin, E., A. (2010), "The Rise in The Sales of Counterfeit Brands: The Case of Turkish Consumers", African Journal of Business Management,4 (10): 2181-2186.

Engel J., F., David T Kollat D., T and, Blackwell R., D. (1968), “Consumer Behavior”, New York, Holt, Rinehart, and Winston.

Furnham, A. and Valgeirsson H. (2007), "The effect of life values and materialism on buying counterfeit products", The Journal of Socio-Economics, No. 36, 677-685.

Festinger, L. (1957). "A Theory of Cognitive Dissonance". Stanford, CA: Stanford University Press.

Ghauri, U. (2014). 65\% Consumer Products Sold In Pakistan Are Fake. Tribune International Press Release.

Gilal, F., G., Zhang, J., Gilal, N., G., and Gilal, R., G. (2018). “Integrating Self-Determined Needs into The Relationship Among Product Design, Willingness-to-Pay A

Sukkur IBA Journal of Management and Business - SIJMB | Vol 7 No. 1 January - June 2020 @ Sukkur IBA University 
Premium, And Word-Of-Mouth: A Cross-cultural Gender-Specific Study". Psychology Research and Behavior Management, 227-241.

Gilal, F., G., Zhang, J., Gilal, N., G., and Gilal, R., G. (2018). “Association Between a Parent's Brand Passion and A Child's Brand Passion: A Moderated ModeratedMediation Model'. Psychology Research and Behavior Management, 91-102.

Gilal, F., G., Zhang, J., Gilal, R., G., Gilal, N., G. (2018). "Linking Motivational Regulation to Brand Passion in A Moderated Model of Customer Gender and Age: An Organismic Integration Theory Perspective", Review of Managerial Science.

Hair, J., F., Black, W., C., and Babin, B., J. (2010). RE Anderson Multivariate data analysis: A global perspective. New Jersey, Pearson Prentice Hall.

Harun, A., Bledram, N., A., A., R., Suki, N., M., and Hussein, Z. (2012), "Why Customers Don't Buy Counterfeit of Luxury Brands? Understanding The Effects of Personality: Perceived Quality and Attitude on Unwillingness to Purchase", Labuan e-Journal of Muamalat and Society, Vol. 6, 14-29.

Hidayat, A., and Diwasasri, A., H. (2013), "Factors Influencing Attitude and Intention to Purchase Counterfeit Luxury Brands Among Indonesian Consumers", International Journal of Marketing Studies, Vol. 5(4), pp. 143-151.

Huang, J. H., Lee, B. C., and Hsun H. S. (2004), "Consumer attitude toward gray market goods", International Marketing Review, 21(6), 598-614.

Hussain, A., Kofinas, A., and Win, S. (2017), "Intention to Purchase Counterfeit Luxury Products: A Comparative Study Between Pakistani and the UK Consumers", Journal of International Consumer Marketing, 331-346.

Husic, M. and Cicic, M. (2009), "Luxury Consumption Factors", Journal of Fashion Marketing and Management, Vol. 13(2), 231-245.

Howard, J., A. (1969). "The Theory of Buyer Behavior". New York: Wiley

Kaiser, H.F. (1958), "The Varimax criterion for analytic rotation in factor analysis", Psychometrika, 23,187-200.

Krishnan, S., Hisyam, F., Ramlan, S., Diyana, N. and Salihah, N. (2017), "Purchase Intention towards Counterfeiting Luxuries Fashion Product among Undergraduate Student in UniKL", American Journal of Economics, 7(1): 29-40.

Kwak, L. E., and Sojka, J. Z. (2010)", If They Could See Me Now: Immigrants Use of Prestige Brands to Convey Status", Journal of Consumer Marketing, Vol. 27(4), 371380.

Malhotra, N. (2010). Marketing Research: An Applied Orientation, 6th ed', New Jersey: Pearson Education Inc.

Mark, M. (2018). Brand Protection Challenges, Domain Management, Anti Fraud Solutions.Mark Monitor Online Barometer.

Mason, R. (2001), "Conspicuous Consumption: A Literature Review", European Journal Of Marketing, Vol. 18(3), 26-39.

Mukhtar, A. H. (2016), "Antecedents of Consumer's Purchase Intention of Counterfeit Luxury Product", Journal of Marketing and Consumer Research, Vol.28, 15-25.

Nguyen, V. P., and Tran, T. T. (2013), "Modeling of Determinants Influence in Consumer Behavior towards Counterfeit Fashion Products", Business Management Dynamics, Vol.2(12), 12-23.

Nguyen, V. P. and Tran, T. T. (2015), "Attitudes and Purchase Intention Towards Counterfeiting Luxurious Fashion Products in Vietnam", International Journal of Economics and Finance, Vol. 7(11), 25-38.

Nordin, N. (2009), "A Study On Consumers Attitude Towards Counterfeit Products in Malaysia", Faculty of Business and Accountancy University of Malaya, 02-107.

Sukkur IBA Journal of Management and Business - SIJMB | Vol 7 No. 1 January - June 2020 @ Sukkur IBA University 
Penz, E., and Stottinger, B. (2008), "Original brands and counterfeit brands-do they have anything in common", Journal of Consumer Behaviour, Vol. 7, 146-163.

Phau, I., and Teah, M. (2009), "Devil Wears (Counterfeit) Prada: A Study of Antecedents and Outcomes of Attitude Towards Counterfeits of Luxury Brands", Journal of Consumer Marketing, Vol. 26(1), 15-27.

Phau, I., Teah, M. and Lee, A. (2009)", Targeting Buyers of Counterfeits of Luxury Brands: A Study On Attitudes of Singaporean,' Consumers", Journal of Targeting, Measurement, and Analysis for Marketing, 03-15.

Ratner, R.K., Kahn, B.E. and Kahneman, D. (1999), "Choosing less-preferred Experiences for The Sake of Variety", Journal of Consumer Research, Vol. 26(1), 01-15.

Roscoe, J. (1975). Fundamentals Research Statistics for Behavioural Sciences', New York: Holt, Rinehart, and Winston.

Schiffman, L.G., and Kanuk, L. L. (1997).Consumers Behavior. Englewood Cliffs', Prentice-Hall. Edition. 8th.

Schneider, M. and Bikoff, J. (2015), "Counterfeiting in the 21st century", Journal of Intellectual Property Law and Practice, Vol. 10(4), 150-178.

Stravinskiene, J., Dovaliene, A. and Ambrazeviciute, R. (2013), "Factors influencing intent to buy counterfeits of luxury goods", Economics and Management, Vol. 18 No. 4, 761-768.

Sandhusen, R. (2000). Marketing, Barrons Educational Series, 110-120.

Tang, F., Tian, V.I. and Zaichkowsky, J. (2014), "Understanding counterfeit consumption", Asia Pacific Journal of Marketing and Logistics, Vol. 26(1), 4-20.

Triandewi, E. and Tjiptono, F. (2013), "Consumer Intention To Buy Original Versus Counterfeits", International Journal Of Marketing Studies, Vol. 5(2), 23-32.

Veloutsou, C. and Bian, X. (2008), "A cross-national examination of consumer perceived risk in the context of non-deceptive counterfeit brands", Journal of Consumer Behaviour, 03-20.

Wang, F., Zang, H., Zhang, H. and Ouyang, M. (2005), "Purchasing Pirated Software: An Initial Examination of Chinese Consumers", Journal of Consumer Marketing, Vol. 22, No. 6, 340-351.

Wu, P. C., Yeh, G. Y. Y., and Hsiao, C. R. (2011), "The effect of store image and service quality on brand image and purchase intention private label brands", Australasian Marketing Journal (AMJ), 19(1), 30-39.

Yoo, B. and Lee, S.H. (2009), "Buy Genuine Luxury Fashion Products or Counterfeits", Advances in Consumer Research, Vol. 36(1), 280-228. 